\title{
NILAI SUN PROTECTION FACTOR ANGGUR LAUT SEGAR DENGAN METODE DAN JENIS PELARUT EKSTRAKSI YANG BERBEDA
}

\author{
Ayun Erwina Arifianti`, Rizky Clarinta Putri, Salsabiela Haz Ekaputri, \\ Wanda Nisrina Aqilah, Effionora Anwar \\ Fakultas Farmasi, Universitas Indonesia, Depok, Jawa Barat
}

*Korespondensi: ayun.arifianti@farmasi.ui.ac.id

Diterima: 2 Desember 2019/Disetujui: 15 April 2020

Cara sitasi: Arifianti AE, Putri RC, Ekaputri SH, Aqilah WN, Anwar E. 2020. Nilai sun protection factor anggur laut segar dengan metode dan jenis pelarut ekstraksi yang berbeda. Jurnal Pengolahan Hasil Perikanan Indonesia. 23(1): 31-37.

\begin{abstract}
Abstrak
Kanker kulit melanoma merupakan satu dari sembilan belas kanker yang sering terjadi di seluruh dunia. Kebutuhan akan adanya alternatif zat aktif tabir surya menjadi sangat penting terutama dari bahan alam laut yaitu anggur laut (Caulerpa sp.). Penelitian ini bertujuan untuk menentukan nilai SPF ekstrak cair anggur laut segar dengan metode ekstraksi yang berbeda. Metode ekstraksi dilakukan dengan dua cara yaitu maserasi dan microwave-assisted extraction (MAE) masing-masing dengan tiga jenis pelarut (etanol, air, dan etanol-air 1:1). Ekstrak cair yang dihasilkan diukur $\mathrm{pH}$ dan ditentukan nilai SPF secara invitro menggunakan spektrofotometer UV-Vis. Ekstrak cair anggur laut segar dengan nilai SPF in vitro tertinggi kemudian dianalisis aktivitas antioksidannya menggunakan metode DPPH. Ekstrak cair yang dihasilkan berbau amis, dan berwarna hijau dengan intensitas warna yang berbeda. Interaksi antara perlakuan metode ekstraksi dan jenis pelarut menunjukkan perbedaan signifikan terhadap nilai $\mathrm{pH}$ ekstrak cair anggur laut segar. Nilai SPF dari ekstrak maserasi etanol, air, dan etanol-air berturut-turut 0,583;3,099; 2,911 sedangkan ekstrak MAE 3,807; 5,555; 4,979. Metode MAE menunjukkan nilai SPF in vitro yang lebih tinggi secara signifikan daripada maserasi tanpa melihat perbedaan pelarut.Hasil persentase penghambatan DPPH dari ekstrak MAE dengan pelarut etanol, air, dan etanol-air pada konsentrasi $106 \mathrm{mg} / \mathrm{mL}$ berturut-turut 33,85\%; 22,99\%; 17,44\%. Aktivitas antioksidan ekstrak etanol dengan metode ekstraksi MAE lebih tinggi daripada ekstrak dengan pelarut lainnya namun tidak lebih tinggi dibandingkan dengan asam askorbat sebagai pembanding.
\end{abstract}

Kata kunci: anggur laut, karakterisasi, maserasi, microwave-assisted extraction, sun protection factor

\section{SPF Value of Fresh Sea Grape Extract from Different Solvent and Method of Extraction}

\begin{abstract}
Skin cancer melanoma is one of the nineteen most prevalent cancers in the world. The needs of skin protecting active ingredients in sunscreen is still high, particularly from marine materials such as sea grapes (Caulerpa sp.). This research was aimed to develop a method that could obtain extract with high in vitro SPF value and antioxidant activity. Two extraction methods (maceration and microwave-assisted extraction) with three different solvents (ethanol, distilled water [DW], and ethanol-DW 1:1) were evaluated. The in vitro SPF value was measured using spectrophotometer UV-Vis, while the antioxidant activity was determined using DPPH. All sea grape extractions yielded in green liquid with different intensity with the odor of fish and $\mathrm{pH}$ value showed significantly different between extraction method and variety of solvent. The extracts obtained using maceration had SPF values 0.583, 3.099; 2.911 when using ethanol, DW and ethanol-DW as a solvent, respectively. Meanwhile the MAE produced extracts with SPF values 3.807; 5.555; 4.979 , respectively. The percentage inhibition of DPPH for the MAE extracts at a concentration of $106 \mathrm{mg} / \mathrm{mL}$ were $33.85 \% ; 22.99 \% ; 17.44 \%$. The MAE extract showed higher in vitro SPF values as compared to the maceration extract. The antioxidant activity in the ethanolic MAE extract was higher than in other solvents but still lower than the ascorbic acid.
\end{abstract}

Keywords: characterization, maceration, microwave-assisted extraction, sea grapes, sun protection factor 


\section{PENDAHULUAN}

Kanker kulit melanoma merupakan satu dari sembilan belas kanker yang sering terjadi di seluruh dunia (GCO 2019). Kanker kulit terbagi menjadi dua jenis yaitu kanker kulit melanoma dan non melanoma. Kanker kulit non melanoma yang sering terjadi adalah karsinoma sel skuamosa (KSS) dan karsinoma sel basal (KSB) (WCRF 2019). Kanker kulit non melanoma terjadi sebanyak 2 hingga 3 juta kasus sedangkan kanker kulit melanoma terjadi sebanyak 132.000 kasus di seluruh penjuru dunia (WHO 2019).

Kanker secara umum $30-50 \%$ dapat dicegah dengan memodifikasi atau menghindari faktor risiko (WHO 2018). Salah satu penyebab kanker kulit adalah paparan sinar ultraviolet (UV). Sinar UV dapat merusak kulit bahkan dengan durasi paparan kurang dari 15 menit (CDC 2019). Radiasi sinar UV bersifat karsinogen (IARC 2007). Apapun warna dan jenis kulit, semua berisiko terkena kanker kulit. Paparan sinar UV dapat tetap terjadi walaupun langit sedang berawan (NIOSH 2010).

Tindakan pencegahan kanker kulit karena paparan radiasi sinar UV adalah menggunakan tabir surya (sunscreen). Penggunaan tabir surya dapat mencegah kanker kulit non melanoma dan bahkan secara drastis dapat menurunkan insiden melanoma yang invasif hingga 73\% (Green et al. 2011). Sampai tahun 2019, terdapat 16 senyawa yang terdaftar di Food and Drug Administration (FDA) untuk digunakan sebagai zat aktif tabir surya. Namun, hanya 2 dari 16 senyawa yang dikategorikan FDA sebagai senyawa yang aman dan efektif (generally recognized as safe and effective-GRASE) yaitu zink oksida dan titanium oksida (FDA 2019).

Kebutuhan akan adanya alternatif zat aktif tabir surya menjadi sangat penting terutama dari bahan alam laut. Salah satunya adalah anggur laut (Caulerpa sp.). Anggur laut banyak terdapat pada perairan Indonesia yang telah terbukti secara in vivo mampu menghambat kerusakan DNA dan photo aging akibat radiasi sinar UV (Wiraguna et al. 2018). Di sisi lain, metode ekstraksi anggur laut yang menghasilkan nilai SPF tertinggi masih belum banyak dikembangkan sebagai alternatif zat aktif tabir surya. Penelitian ini bertujuan untuk membuat ekstrak cair anggur laut segar dengan dua metode ekstraksi yaitu maserasi dan microwave-assisted extraction (MAE) dengan masing-masing metode menggunakan tiga jenis pelarut berbeda (etanol, air, dan etanol-air perbandingan 1:1) untuk menentukan karakteristik ekstrak dan nilai SPF in vitro tertinggi serta aktivitas antioksidan pada metode tersebut.

\section{BAHAN DAN METODE Bahan dan Alat}

Bahan yang digunakan dalam penelitian ini adalah anggur laut yang diperoleh dari Pantai Anyer di Banten, Jawa Barat. Pelarut yang digunakan untuk ekstraksi adalah aquadestilata (Brataco, Indonesia), dan etanol teknis 96\% (Dwinika, Indonesia). Bahan pengujian antioksidan meliputi etanol p.a (Merck, Indonesia), dan DPPH (2,2- difenil-1 -pikrilhidrazil) (TCI, Jepang).

Alat yang digunakan berupa microwave (Modena MV 3002, Italia), spektrofotometer UV-Vis (Shimadzu 1800, Jepang), pH-meter tipe 510 (Eutech Instrument, Singapura), sentrifugator (Kubota 5100, Jepang), timbangan analitik tipe 210-LC (ADAM, Amerika Serikat), lemari pendingin (Toshiba, Jepang), rotary vacuum evaporator (Buchi R205, Swiss), blender (Philips, Indonesia), pipet mikro (Eppendorf, Jerman), dan alatalat gelas untuk analisis.

\section{Metode Penelitian Ekstraksi anggur laut}

Metode ekstraksi dengan microwave yang digunakan mengikuti Li et al. (2012) sedangkan metodeekstraksi maserasi mengikuti Anwar et al. (2018) dengan modifikasi. Anggur laut segar dibersihkan dari kotoran dan dicuci dengan air mengalir, kemudian ditimbang sebanyak 5 gram dan diblender. Hasil blender dimasukkan ke dalam labu lalu ditambahkan pelarut $250 \mathrm{~mL}$ dan diekstraksi dengan microwave (MAE) pada daya $100 \mathrm{~W}$ selama 30 menit. Pelarut yang digunakan terdiri dari tiga jenis yaitu air, etanol 96\% dan campuran air dan etanol 96\% perbandingan 1:1.

Anggur laut segar dibersihkan dengan cara yang sama dengan metode MAE untuk 
digunakan pada metode maserasi. Anggur laut bersih ditimbang sebanyak 250 gram dan ditambahkan pelarut sebanyak 2,5 L dan dimaserasi selama $2 \times 24$ jam. Pelarut yang digunakan sama dengan metode MAE yaitu air, etanol 96\% dan campuran air dan etanol 96\% perbandingan 1:1. Masing-masing ekstrak yang dihasilkan dari metode MAE dan maserasi disaring dan filtrat yang dihasilkan merupakan ekstrak cair yang akan digunakan untuk tahap selanjutnya.

\section{Ekstrak anggur laut}

Ekstrak cair dengan pelarut dan metode ekstraksi yang berbeda diamati warna dan baunya secara visual dan dilakukan pengukuran $\mathrm{pH}$. Pengujian $\mathrm{pH}$ dilakukan pada $20 \mathrm{~mL}$ ekstrak dengan menggunakan $\mathrm{pH}$ meter yang telah dikalibrasi. Pengujian dilakukan duplo dan dihitung nilai rata-rata $\mathrm{pH}$ yang didapat.

\section{Pengujian sun protection factor (SPF) ekstrak anggur laut}

Masing-masing ekstrak cair anggur laut sebanyak 1,5 mL dimasukkan ke dalam kuvet kemudian diukur nilai absorbansinya menggunakan spektrofotometer UV-Vis. Serapan diukur pada panjang gelombang 290 $320 \mathrm{~nm}$ mengikuti metode Dutra et al. (2004) dengan modifikasi. Secara teori, sinar UV terbagi menjadi tiga jenis berdasarkan panjang gelombang dan efek radiasi yang dihasilkan yaitu sinar UV A, B dan C. Panjang gelombang sinar UV A adalah 320-400 nm, sinar UV B 290-320 nm, dan sinar UV C sebesar 200$290 \mathrm{~nm}$. Sinar UV B dibandingkan dengan sinar lainnya memiliki efek eritema dan pada paparan kronis dapat menyebabkan kanker. Oleh karena itu, pada pengujian SPF ini digunakan rentang panjang gelombang sinar UV B yaitu 290-320 nm (Tranggono et al. 2007). Perhitungan nilai SPF menggunakan perhitungan Mansur (Mansur et al. 1986) sebagai berikut:

Nilai SPF in vitro $=F K \times \sum_{290}^{320} E E(\lambda) \times \boldsymbol{I}(\lambda) \times(A \lambda)$ Keterangan:

Perkalian $\operatorname{EE}(\lambda)$ dan $\mathrm{I}(\lambda)$ adalah suatu tetapan yang diperoleh dari literatur (Sayre et al.,1979)

FK adalah faktor koreksi yaitu 10

$\mathrm{A}(\lambda)$ diperoleh dari percobaan

\section{Pengujian antioksidan ekstrak anggur laut}

Penentuan aktivitas antioksidan dilakukan mengikuti Anwar et al. (2018) dengan modifikasi. Ketiga ekstrak cair dengan hasil uji SPF in vitro yang tertinggi ditimbang dan diencerkan dengan pelarut etanol p.a yang dibuat dalam konsentrasi $106 \mathrm{mg} / \mathrm{mL}$. Kemudian masing-masing sampel dipipet sebanyak $2 \mathrm{~mL}$ lalu ditambahkan $1 \mathrm{~mL}$ pelarut etanol p.a dan larutan DPPH-etanol masingmasing sebanyak $1 \mathrm{~mL}$ serta divortex selama 20 detik. Sampel diletakkan di tempat gelap selama 30 menit, lalu diukur serapan larutan pada panjang gelombang maksimum DPPH yang telah dioptimasi sebelumnya.

\section{Analisis Data}

Analisis data berupa perbandingan nilai $\mathrm{pH}$ dan SPF in vitro dari masing-masing ekstrak dilakukan dengan uji two-way ANOVA menggunakan IBM SPSS 21.

\section{HASIL DAN PEMBAHASAN Ekstrak Cair Anggur Laut}

Ekstrak cair yang didapatkan adalah berbau amis dan berwarna hijau dengan intensitas warna yang berbeda (Figure 1). Ekstrak etanol dari kedua metode ekstraksi memiliki warna hijau yang paling pekat. Warna hijau pekat yang didapatkan pada ekstrak tersebut kemungkinan menunjukkan adanya kandungan pigmen klorofil karena kelarutannya yang baik pada pelarut organik seperti etanol (Hosikian et al. 2010). Caulerpa sp. sebagai bagian dari alga hijau dilaporkan oleh Fajar et al. (2014) memiliki kandungan pigmen klorofil terbanyak dibandingkan dengan beta karoten dan caulerpin.

Hasil pengukuran $\mathrm{pH}$ ekstrak (Table 1) menunjukkan terdapat interaksi yang signifikan antara metode ekstraksi dan perbedaan pelarut terhadap $\mathrm{pH}, \mathrm{F}(2,6)$ $=185,641, \mathrm{p}<0,001$. Selain itu, terdapat perbedaan $\mathrm{pH}$ yang signifikan antar metode ekstraksi $(\mathrm{p}<0,001)$ dan perbedaan pelarut $(\mathrm{p}<0,001)$. Pengujian $\mathrm{pH}$ dilakukan untuk memastikan stabilitas senyawa polifenol yang diharapkan terdapat pada ekstrak karena struktur kimia dari senyawa polifenol 


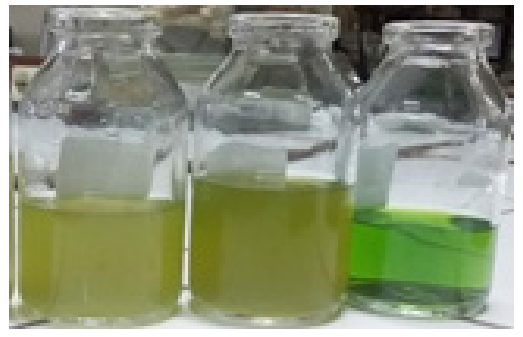

(a)

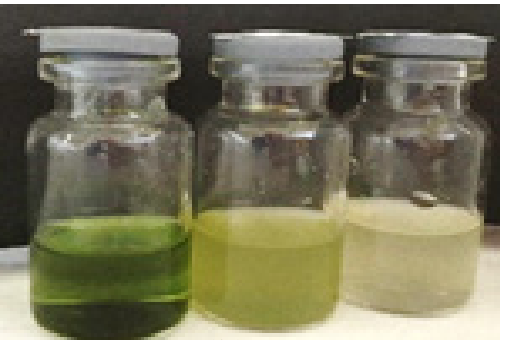

(b)

Figure 1 Sea grape extracts using maceration method (a) and MAE (b). From left to right, ethanol, distilled water:ethanol, and distilled water extract.

menunjukkan kerentanan saat terpapar pada pH tinggi (Friedman et al. 2000).

Pemilihan pelarut pada penelitian ini dilakukan berdasarkan polaritas metabolit sekunder yang terkandung pada anggur laut yang dilaporkan Wiraguna et al. (2018) mengandung senyawa polifenol. Metode ekstraksi secara maserasi menggunakan prinsip difusi pelarut ke dalam dinding sel sehingga zat-zat yang terkandung di dalamnya akan terlarut (Ansel 2005), sedangkan metode MAE menggunakan panas yang dihasilkan dari gelombang mikro yang berinteraksi dengan senyawa polar dan beberapa komponen organik dalam matriks tanaman mengikuti mekanisme konduksi ion dan rotasi dipol (Zhang et al. 2018). Penggunaan MAE memberikan lebih banyak kelebihan di antaranya waktu ekstraksi yang lebih singkat, konsumsi energi dan penggunaan pelarut yang lebih rendah dibandingkan dengan metode konvensional.

\section{Nilai SPF In Vitro Ekstrak Anggur Laut}

SPF secara in vitro merupakan hasil perlindungan mutlak dari tabir surya terhadap eritema akibat radiasi UV yang dihitung berdasarkan transmisi in vitro pada spektrum aksi eritema dibandingkan dengan standar spektrum dari simulator sinar UV (Donglikar et al. 2016). Pengujian SPF in vitro dilakukan dengan tujuan untuk mengkarakterisasi serapan UV dari larutan uji menggunakan alat spektrofotometri UVVis. Berdasarkan Table 2, nilai SPF in vitro ekstrak anggur laut dari metode MAE secara signifikan lebih tinggi daripada maserasi $(\mathrm{p}=0,019)$, tetapi tidak terdapat perbedaan antar pelarut yang digunakan dalam MAE masing-masing metode $(\mathrm{p}=0,226)$. Dalam proses ekstraksi secara MAE, molekul polar mengabsorbsi energi microwave sehingga disrupsi sel menjadi tidak terhindarkan (Cikos et al. 2018). Hal ini menyebabkan ekstraksi senyawa lebih sempurna dibandingkan metode konvensional seperti maserasi. Menurut Cikos et al. (2018), senyawa yang sering didapatkan dari MAE adalah polifenol dan polisakarida. Senyawa fenol kemungkinan dapat berguna dalam menghambat UV yang diinduksi oleh pembentukan radikal bebas oksigen dan peroksidasi lipid (Ebrahimzadeh et al. 2014). Penelitian yang dilakukan oleh Li et al. (2012) menyarankan bahwa MAE dapat menjadi cara yang efektif dalam mengekstrak kandungan fenol dari Caulerpa racemosa dengan waktu yang singkat karena mengurangi degradasi suhu dari senyawa fenol. Nurjanah et al. (2019) pun melaporkan hal yang sama pada penelitian dengan Caulerpa sp. segar dan direbus yaitu suhu tinggi dapat melarutkan atau mengoksidasi kandungan senyawa flavonoid.

Table $1 \mathrm{pH}$ Test Result of Sea Grapes Extract

\begin{tabular}{ccccccc}
\hline & \multicolumn{3}{c}{ Maceration } & \multicolumn{3}{c}{ MAE } \\
\cline { 2 - 6 } & Ethanol $^{\mathrm{a}}$ & Distilled Water $^{\mathrm{b}}$ & DW-ethanol $^{\mathrm{c}}$ & Ethanol $^{\mathrm{d}}$ & Distilled Water $^{\mathrm{e}}$ & DW-ethanol $^{\mathrm{f}}$ \\
\hline $\mathrm{pH}$ & $7.20 \pm 0.00$ & $7.37 \pm 0.02$ & $7.67 \pm 0.01$ & $7.66 \pm 0.04$ & $7.28 \pm 0.04$ & $8.13 \pm 0.01$ \\
& & & & & & \\
\hline
\end{tabular}

Information: Uppercase letters indicated significant differences between treatment $(\mathrm{p}<0.05)$, two-way ANOVA. 
Table 2 SPF Value from Sea Grapes Extract with Maceration and MAE

\begin{tabular}{lcccccc}
\hline \multirow{2}{*}{ Wavelength } & \multicolumn{3}{c}{ SPF Value for Maceration ${ }^{\mathrm{a}}$} & \multicolumn{3}{c}{ SPF Value for MAE $^{\mathrm{b}}$} \\
\cline { 2 - 6 } & Ethanol & Distilled Water & DW-ethanol & Ethanol & Distilled Water & DW-ethanol \\
\hline 290 & 0.062 & 0.409 & 0.203 & 0.445 & 0.535 & 0.548 \\
295 & 0.315 & 1.768 & 1.479 & 2.730 & 3.063 & 2.905 \\
300 & 1.126 & 6.636 & 5.892 & 8.030 & 11.496 & 11.076 \\
305 & 1.344 & 5.727 & 5.739 & 7.589 & 12.778 & 10.607 \\
310 & 0.816 & 5.476 & 5.141 & 5.038 & 7.193 & 6.915 \\
315 & 0.347 & 1.410 & 1.723 & 2.302 & 3.098 & 2.377 \\
320 & 0.066 & 0.268 & 0.199 & 0.514 & 0.720 & 0.419 \\
mean & 0.583 & 3.099 & 2.911 & 3.807 & 5.555 & 4.979 \\
\hline
\end{tabular}

Information: Uppercase letters indicated significant differences between treatment $(\mathrm{p}<0.05)$, two-way ANOVA.

Nilai SPF dari maserasi yang didapatkan tidak jauh berbeda dengan penelitian Ersalina et al. (2020) yang menghasilkan nilai SPF berkisar antara 1,03-2,32 menggunakan $1 \%$ ekstrak maserasi dengan pelarut $n$-heksan, etil asetat dan etanol dari Caulerpa racemosa dalam sediaan krim.

\section{Aktivitas Antioksidan Ekstrak MAE Anggur Laut}

Penentuan aktivitas antioksidan ekstrak Anggur Laut pada metode terpilih dilakukan dengan metode DPPH yang dikenal sebagai metode yang popular menurut Molyneux (2004). Pengujian menggunakan larutan DPPH ini dilakukan pada panjang gelombang maksimum $504 \mathrm{~nm}$. Asam askorbat yang digunakan sebagai baku pembanding menghasilkan nilai $\mathrm{IC}_{50} 0,0045 \mathrm{mg} / \mathrm{mL}$ sehingga membuktikan metode pengujian sudah sesuai standar.

Anggur laut mengandung berbagai agen antioksidan seperti polifenol (Wiraguna et al. 2018). Polifenol adalah antioksidan kuat dan suplemen makanan penting bagi manusia (Nguyen et al. 2011). Polifenol mampu mendonorkan atom hidrogen dan menangkap radikal bebas (Lee et al. 2004). Penelitian yang dilakukan oleh Nufus et al. (2017) dan Susilowati et al. (2019) melaporkan Caulerpa lentillifera dan Caulerpa racemosa mengandung senyawa fenol dan flavonoid yang menunjukkan aktivitas antioksidan.

Uji aktivitas antioksidan ekstrak hanya dilakukan pada metode ekstraksi yang memiliki nilai SPF tertinggi secara signifikan yaitu metode MAE karena senyawa alami yang bersifat antioksidan seperti polifenol (flavonoid) dikenal dapat digunakan sebagai tabir surya melalui mekanisme penghambatan radikal bebas yang dihasilkan dari kerusakan kulit akibat radiasi UV (Donglikar et al. 2016). Pengujian antioksidan pada ekstrak anggur laut hanya dapat dilakukan menggunakan persentase inhibisi pada konsentrasi paling rendah yang dilakukan yaitu $106 \mathrm{mg} / \mathrm{mL}$ dengan pengulangan duplo (Table 3). Hal ini dikarenakan data pengujian dengan berbagai konsentrasi ekstrak yang didapatkan menghasilkan kurva yang tidak linear untuk nilai $\mathrm{IC}_{50}$. Berdasarkan hasil pengujian yang dilakukan, didapatkan nilai persentase penghambatan ekstrak etanol yang lebih tinggi dibandingkan pelarut lainnya, namun nilai tersebut lebih rendah daripada asam askorbat.

\section{KESIMPULAN}

Ekstrak cair anggur laut yang dihasilkan berbau amis, dan berwarna hijau dengan intensitas warna yang berbeda serta menunjukkan adanya perbedaan $\mathrm{pH}$ yang

Table 3 Antioxidant result with DPPH method from MAE extract

\begin{tabular}{cc}
\hline MAE Extract & Inhibition Percentage (\%) \\
\hline Ethanol $106 \mathrm{mg} / \mathrm{mL}$ & 33.85 \\
Distilled Water $106 \mathrm{mg} / \mathrm{mL}$ & 22.99 \\
DW-ethanol $106 \mathrm{mg} / \mathrm{mL}$ & 17.44 \\
\hline
\end{tabular}


signifikan antar metode ekstraksi dan jenis pelarut yang berbeda.

Metode microwave-assisted extraction menunjukkan nilai SPF in vitro yang lebih tinggi secara signifikan daripada maserasi tanpa melihat perbedaan pelarut. Aktivitas antioksidan pada ekstrak MAE etanol lebih tinggi daripada pelarut lainnya namun tidak lebih tinggi dibandingkan dengan asam askorbat sebagai pembanding.

\section{UCAPAN TERIMA KASIH}

Penulis mengucapkan terima kasih kepada Fakultas Farmasi, Universitas Indonesia dalam pendanaan melalui Hibah IRP A untuk Dosen Muda. Penulis pula mengucapkan terima kasih kepada Rini, Denny, dan Ibu Anna yang telah membantu penelitian ini.

\section{DAFTAR PUSTAKA}

Ansel HC. 2005. Pengantar Bentuk Sediaan Farmasi. Edisi keempat. Jakarta (ID): UI Press.

Anwar E, Yulianti D, Putri KSS. 2018. Stability of microsphere of Sargassum plagyophyllum (Mertens) J. G. Agardh extract produced by spray drying using maltodextrin. International Journal of Applied Pharmaceutics. 10: 376.

Donglikar MM, Deore SL. 2016. Sunscreens: A review. Pharmacognosy Journal 8(3): 171-179

Dutra EA, Oliveira DAGC, KedorHackmann ERM, Santoro MIRM. 2004. Determination of sun protection factor (SPF) of sunscreens by ultraviolet spectrophotometry. Brazilian Journal of Pharmaceutical Sciences. 40: 3.

[CDC] Center for Disease Control and Prevention. 2019. Sun Protection. www. cdc.gov.

Cikos AM, Jokic S, Subaric D, Jerkovic I. 2018. Overview on the application of modern methods for the extraction of bioactive compounds from marine macroalgae. Marine Drugs. 16: 348.

Ebrahimzadeh MA, Enayatifardb R, Khalilia M, Saeedi MGM, Charati Y. 2014. Correlation between Sun Protection Factor and Antioxidant Activity, Phenol and Flavonoid Contents of some
Medicinal Plants. Iranian Journal of Pharmaceutical Research. 13(3): 10411047

Ersalina EB, Abdillah AA, Sulmartiwi L. 2020. Potential of Caulerpa racemosa extracts as sunscreen creams. IOP Conference Series: Earth and Environmental Science. 441: 012007

Fajar A, Ibrahim R, Dewi EN. 2014. Jurnal Pengolahan dan Bioteknologi Hasil Perikanan. 3(1): 1-10.

[FDA] Food and Drug Administration. 2019. FDA Advances new proposed regulation to make sure that sunscreens are safe and effective. www.fda.gov.

[FDA] Food and Drug Administration. 2019. Sunscreen: How to Help Protect Your Skin From the Sun. www.fda.gov.

Friedman M, Jurgens HS. 2000. Effect of $\mathrm{pH}$ on the Stability of Plant Phenolic Compounds. Journal of Agricultural and Food Chemistry. 48: 2101-2110.

[GCO] The Global Cancer Observatory. 2019. Indonesia Fact Sheet. www.gco.iarc.fr.

Green AC, Williams GM, Logan V, Strutton GM. 2011. Reduced melanoma after regular sunscreen use: randomized trial follow-up. Journal Clinic Oncology. 29(3): 257-263.

Hosikian A, Lim S, Halim R, Danquah MK. 2010. Chlorophyll extraction from microalgae: A review on the process engineering aspects. International Journal of Chemical Engineering. 2010: 1-11.

[IARC] International Agency for Research on Cancer. 2007. IARC Monographs on the Evaluation of Carcinogenic Risks to Humans. Lyon (FR): IARC.

Lee J, Koo N, Min DB. 2004. Reactive oxygen species, aging, and antioxidative nutraceuticals. Comprehensive Reviews in Food Science and Food Safety. 3:21-33

Li Z, Wang B, Zhang Q, Qu Y, Xu H, Li G. 2012. Preparation and antioxidant property of extract and semipurified fractions of Caulerpa racemosa. Journal of Applied Phycology. 24: 1527-1536.

Mansur JS, Breder MN, Mansur MC, Azulay RD. 1986. Determination of Sun protection factor by spectrophotometry. Anais Brasileiros de Dermatologia. 61: 
121-4.

Molyneux P. 2004. The use of the stable free radical diphenylpicryl-hydrazyl (DPPH) for estimating antioxidant activity. Songklanakarin Journal of Science and Technology. 26(2): 211-219.

[NIOSH] The National Institute of Occupational Safety and Health. 2010. NIOSH Fact Sheets: Protecting yourself from sun exposure.www.cdc.gov.

Nguyen VT, Ueng JP, Tsai GJ. 2011. Proximate Composition, Total Phenolic Content, and Antioxidant Activity of Seagrape (Caulerpa lentillifera). Journal of Food Science. 76(7): C950-C958.

Nufus C, Nurjanah, Abdullah A. 2017. Karakteristik rumput laut hijau dari perairan Kepulauan Seribu dan Sekotong Nusa Tenggara Barat sebagai antioksidan. Jurnal Pengolahan Hasil Perikanan Indonesia. 20(3): 620-632.

Nurjanah, Jacoeb AM, Asmara DA, Hidayat T. 2019. Phenolic compound of fresh and boiled sea grapes (Caulerpa sp.) from Tual, Maluku. Food ScienTech Journal. 1(1): 31-39.

Sayre RM, Agin PP, Levee GI, Marlowe E. 1979.
Comparison of in vivo and in vitro testing of sunscreening formulas. Photochemistry and Photobiology. 559-566.

Susilowati A, Mulyawan AE, Putri TW. 2019. Antioxidant Activity of the Sea Grape (Caulerpa racemasa) Used As an Antioxidant Lotion. Oriental Journal of Chemistry. 35(4): 1443-1447

Tranggono RI, Latifah F. 2007. Buku Pegangan Ilmu Pengetahuan Kosmetik. Jakarta (ID): PT Gramedia Pustaka Utama.

Wiraguna A, Pangkahila W, Astawa I. 2018. Antioxidant properties of topical Caulerpa sp. extract on UVB-induced photoaging in mice. Dermatology reports. 10(2): 7597.

[WCRF] World Cancer Research Fund. 2019. Global Cancer data by country: exploring which countries have the highest cancers rate. www.wcrf.org

[WHO] World Health Organization. 2019. Skin Cancers. www.who.int.

[WHO] World Health Organization. 2018. Cancer Prevention. www.who.int.

Zhang QW, Lin LG, Ye WC. 2018. Techniques for extraction and isolation of natural products: a comprehensive review. Chinese medicine. 13: 20. 